\author{
Martynas Zapolskis \\ Institute of International Relations and Political Science, Vilnius University
}

\title{
1999 and 2010 NATO Strategic Concepts: A Comparative Analysis
}

This article uses cooperative security theory to examine and compare 1999 and 2010 NATO Strategic Concepts, thus assessing the main developments of NATO transformation during the last decade. Analysis shows that the new Strategic Concept is a more "evolutionary" than "revolutionary" document, as the main elements and functions of the Alliance remain unchanged. New strategy projects NATO as a multifunctional security structure, which combines collective security and collective defence dimensions on the one hand with active policy of promoting stability (operations and partnerships) on the other. The most important difference between 1999 and 2010 documents is the multifunctional character and high level of ambitions in the new strategic plan in such areas as civilian capabilities, missile defence, cyber security, NATO-EU relations, etc. The new Strategic Concept modernized NATO and demonstrated solidarity about the main tasks of the Alliance. Nevertheless, actual implementation of this ambitious agenda depends on the ability to address deeply rooted internal problems (such as increasing gap between the US and Europe), which will require a favourable international environment, considerable resources and strong political will by the Allies.

\section{Introduction}

The new NATO Strategic Concept adopted at the Lisbon Summit in November 2010 is a key document of the Alliance, which identifies the purpose and tasks of NATO, assesses the international security environment and defines relations with other international actors. It is the seventh Strategic Concept since the inception of the organization in 1949. The previous Strategic Concept was adopted in 1999 - the year in which NATO started its first "out of area" operation in Kosovo, which highly influenced the content of the document.

The purpose of this article is to examine and compare the 1999 and 2010 Strategic Concepts, thus assessing the main developments of NATO transformation during the last decade. Strategic Concepts are considered the key political documents that reflect a compromise between the Allies about NATO's tasks,

\footnotetext{
* Martynas Zapolskis is a PhD candidate at the Institute of International Relations and Political Science, Vilnius University. Address for correspondence: Vokiečiu 10, LT-01130 Vilnius, Lithuania, tel. +370 5 2514130,martynas.zapolskis@tspmi.vu.lt
} 
mark historical turning points in the Alliance's history and reveal the crucial comparative issues of NATO then (1999) and now (2010). Importantly, the NATO Strategic Concept is not just a political declaration; it is the key NATO defence planning document, defining guidelines and the level of ambition, which is subsequently transformed into real capabilities, initiatives, reforms and operations.

The analysis will be conducted within the framework of cooperative security theory. Cooperative security focuses on four "strategic rings" ${ }^{1}$, connecting different dimensions of the international system, characterized by various formal and informal institutions. Such a system consists of highly interdependent democratic states, which are related by common values and close practical cooperation in various fields. ${ }^{2}$

The article consists of three parts. The first part briefly presents the theoretical background - the concept of cooperative security. The second part identifies and reviews the main features of NATO as a cooperative security system. The third part uses the four dimensions of cooperative security to examine, compare and assess 1999 and 2010 NATO Strategic Concepts.

\section{Theoretical Guidelines: the Cooperative Security Model}

In the context of the wide spectrum of international security studies NATO is usually analysed as a structure that allows the empirical assessment or illustration of various theoretical concepts of international relations. To summarize different strands of NATO studies in the academic literature, four main theoretical constructs can be identified, suggesting different interpretations of international relations, as well as specific explanation(s) of NATO transformation. These are the theories of (1) security communities, (2) alliances, (3) collective security and (4) cooperative security.

\footnotetext{
${ }^{1}$ Individual security, collective security, collective defence and promoting stability.

${ }^{2}$ Cohen R., "From Individual Security to International Stability." In Cohen, R., Mihalka M., Cooperative Security: New Horizons for International Order. Garmisch - Partenkirchen: The George C. Marshall European Center for Security Studies, 2001, p. 10.
} 
The concept of security community ${ }^{3}$ is mostly based on (inter)subjective ontology and assumes that states are able to develop collective identity. Common values, norms and symbols generate common identity, which creates conditions for stability and peace. ${ }^{4}$ In terms of NATO studies and practical application of constructivism-based concept of security community, the focus of analysis is concentrated on the identity and common values of the NATO member states and other international actors.

The theory of alliances is mostly based on (neo)realist explanation of international relations, assuming that international system, national interests and security policy are related by close causal relations. The anarchic character of international relations determines rational interest to enhance the power and security, various forms of interstate relations (such as alliances) therefore are regarded a consequence of such rationale. ${ }^{5}$ Accordingly, alliances are considered as directed against other subject or group, some sort of "enemy" or "threat" is always needed to justify their existence. ${ }^{6}$ Such approach, though consistent from methodological perspective, is basically restricted to the analysis of material factors and ignores normative issues. Moreover, this approach cannot adequately assess fundamental post-Cold War changes of international security environment, which are one of the key driving forces of contemporary NATO.

\footnotetext{
${ }^{3}$ Further on the theory of security community introduced by K. Deutsch (Deutsch, K., Political Community and the North Atlantic Area. Princeton, NJ: Princeton University Press, 1957) and its application for NATO research see: Adler, E., „The Spread of Security Communities: Communities of Practice, Self-Restraint, and NATO's Post-Cold War Transformation", European Journal of International Relations, 14 (12), 2008; RisseKappen, Thomas, „Identity in a Democratic Security Community: The Case of NATO“, in Katzenstein, Peter J., (ed.), The Culture of National Security. New York: Columbia University Press, 1996; Williams, M., Neumann, I., „From Alliance to Security Community: NATO, Russia, and the Power of Identity“, Millennium - Journal of International Studies, 29 (2), 2000; Pouliot, V., "The Alive and Well Transatlantic Security Community: A Theoretical Reply to Michael Cox", European Journal of International Relations 2006; Vol. 12(1), p. 119-127; Ivanov, I. D., „NATO's Transformation and its Implications for International Relations Theory: The Relevance of Security Communities", Paper presented at the annual meeting of The Midwest Political Science Association, 2006; Kitchen, V. M., „Argument and Identity Change in the Atlantic Security Community“, Security Dialogue, 40(1), 2009, p. 95-114.

${ }^{4}$ Adler, E., Barnett, M., "Security Communities in Theoretical Perspective“, in Adler, E., Barnett, M., (ed.), Security Communities. Cambridge: Cambridge University Press, 1998.

${ }^{5}$ Neorealist explanation of alliance theory was developed by Walt, S., The Origins of Alliances, Ithaca, NY: Cornell University Press, 1990; Snyder, G. H., „Alliances, Balance, and Stability“, International Organization“, 45(1), 1991, p. 121-42; also see: Sprecher, C., Krause, V., „Alliances, Armed Conflict, and Cooperation: Theoretical Approaches and Empirical Evidence", Journal of Peace Research, 43(4), 2006, p. 363-369.

For NATO research within the framework of alliance theory see: Sandler, T., „Alliance Formation, Alliance Expansion, and the Core“, Journal of Conflict Resolution, 43(6), 1999, 727-747; Gibler, D., Sewell, J. A., „External Threat and Democracy: The Role of NATO Revisited“, Journal of Peace Research, 43(4), 2006, p. 413-431; Snyder, G. H., „The Security Dilemma in Alliance Politics“, World Politics, 36(4), 1984, p. 461-495 ${ }^{6}$ Liska, G., Nations in Alliance: the Limits of Interdependence. Baltimore: Johns Hopkins University Press, 1967.
} 
Collective security theory is closely related with the Wilsonist tradition of international relations and the English (International Society) school. The concept of collective security assumes that certain group of states, acting in the anarchic international environment and having common purposes and values, compose a collective structure, in which states retain their sovereignty but agree to follow certain principles and norms (for example, with regard to the rules and means of using military force). ${ }^{7}$ The concept of collective security is suitable for explaining the cooperation between states (i.e. the internal mechanism of collective security system) however, it does not pay proper attention to systemic factors (especially, various aspects of international security).

The analysis in this article is conducted on the basis of the cooperative security model developed by R. Cohen and M. Mihalka. The concept of cooperative security emerged after the Cold War; however, it did not have a proper conceptual background and was mostly used to describe a "new international order", which is defined by consultations instead of confrontation, transparency instead of secrecy, reassurance instead of deterrence. ${ }^{8}$

According to R. Cohen, the cooperative security system includes four dimensions (concentric rings): (1) individual security; (2) collective security; (4) collective defence; (4) promoting stability: ${ }^{9}$

The individual security dimension (the first concentric ring) is focused on human security aspects (human rights, democratic values, well being, etc.), which overcome national boundaries and consider security as a broad concept, including various parameters of economic welfare and sustainable development. It is an internal ring of the system, which can be considered some sort of "social glue" (various principles of liberal democracy) ensuring internal systemic stability and resistance.

The collective security dimension (the second concentric ring) is directed towards the internal dimension of the system in terms of ensuring security between sovereign

\footnotetext{
${ }^{7}$ For detailed review of collective security theory see: Ravenal, E.C., „An Autopsy of Collective Security“, Political Science Quarterly, 90(4), 1976, 697-714. For application of collective security theory for NATO see: Kupchan, C., ,The Promise of Collective Security“, International Security, 20(1), 1995, p. 52-61; Yost, D., NATO Transformed: The Alliance's New Role in International Security, Washington: United States Institute of Peace Press, 1998; also see: Johnson, H.C., G. Niemeyer, „Collective Security: The Validity of an Ideal“, International Organization, 8(1), 1954, p. 19-35, Cusack, T.R., Stoll, R.J., „Collective Security and State Survival in the Interstate", International Studies Quarterly, 38(1), 1994, p. 33-59.

${ }^{8}$ Evans, Gareth, „Cooperative Security and Intra-State Conflict,“ Foreign Policy, No. 96, Fall 1994, in Cohen and Mihalka, p. 4.

${ }^{9}$ According to Cohen, R., "From Individual Security to International Stability", in Cohen, R., Mihalka, M., Cooperative Security: New Horizons for International Order. Garmisch - Partenkirchen: The George C. Marshall European Center for Security Studies, 2001, p. 5-10.
} 
states. It is focused on ensuring internal peace and the elimination of threats rising from other actors of the security system. The collective security dimension includes various forms of cooperation between the members of the system in such areas as terrorism, organized crime, illegal immigration, natural disasters, etc.

Collective defence (the third concentric ring) is directed towards the external dimension of the system, focusing on defence from external aggression (various state and non-state actors outside the system). Members of the system commit to ensure credible defence and effective response to external aggression or similar threats. In practice, it can be institutionalized as various mechanisms and interstate agreements of collective defence.

The dimension of promoting stability (the fourth concentric ring) defines the prevention of instability outside the system. Potential sources of instability are eliminated by using various political, economic, diplomatic and military measures, establishing international cooperation mechanisms, etc. In practice, it can be realized as a commitment to protect specific kind of value system (human rights, etc.), prevent evolving threats (e.g. WMD proliferation) or enable various institutional cooperation/confidence building mechanisms.

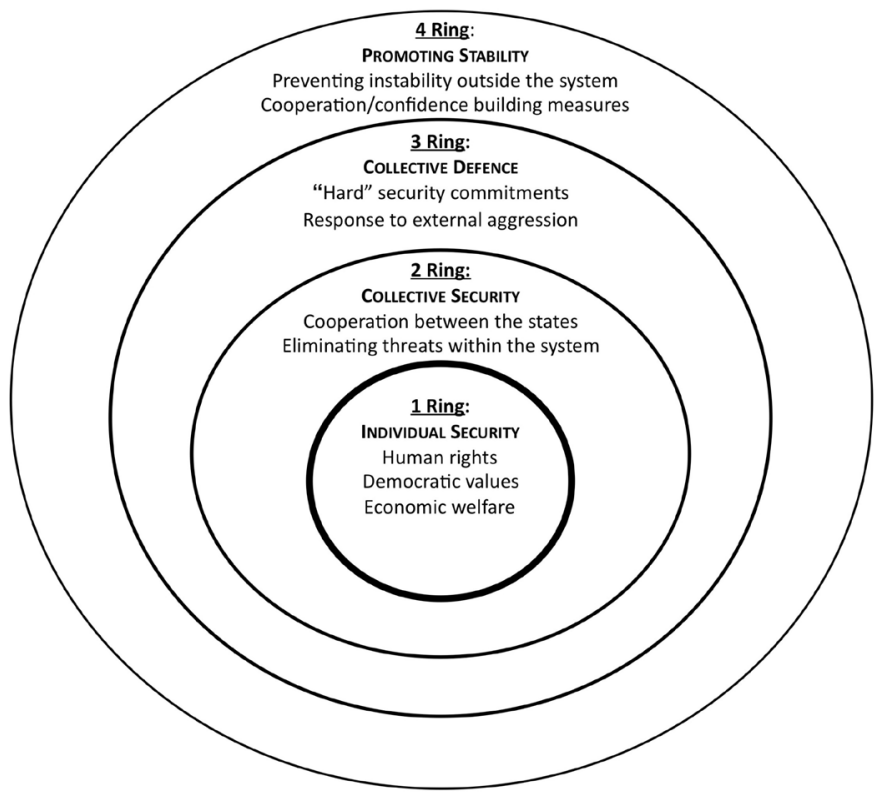

Figure 1. Theoretical model of cooperative security system ${ }^{10}$

\footnotetext{
${ }^{10}$ Adapted according to Cohen, R., "From Individual Security to International Stability", in Cohen, R., Mihalka, M., Cooperative Security: New Horizons for International Order. Garmisch - Partenkirchen: The George C. Marshall European Center for Security Studies, 2001, p. 5-10.
} 


\section{NATO as a Cooperative Security System: the Main Features}

Before focusing on the analysis of Strategic Concepts, it is important to answer the question of the extent to which NATO can be regarded as a cooperative security system.

The first ring. All NATO countries can be considered liberal democracies committed to the key principles of human rights. NATO's rhetoric and activities have a strong element of collectiveness based on common values. The role of the Alliance in the field of promoting democratic culture and strengthening democratic institutions is also often emphasized in strategic documents and public announcements by NATO representatives. For example, the North Atlantic Treaty highlights that NATO members "are determined to safeguard the freedom, common heritage and civilisation of their peoples, founded on the principles of democracy, individual liberty and the rule of law. They seek to promote stability and well-being in the North Atlantic area."

In addition, emphasis is often put on NATO's intention to create structural stability conditions that would enable the promotion of human rights, democratic reforms and the development of economy. ${ }^{12}$

The second ring. NATO can be considered the most important institutional and political expression of the transatlantic link, which is based the principle of indivisible security between North America and Europe, thus eliminating the balance of power within the system and allowing a renewed focus on external security challenges.

Since its inception NATO was able to neutralize (or restrain) sources of tension between NATO members. For example, intensive use of consultation and cooperation mechanisms helped to avoid military conflict between Turkey and Greece (both countries were accepted to NATO in 1952, facing high tensions over Cyprus) and mitigate other bilateral crises.

Various channels of NATO political consultations (article 4 of the North Atlantic Treaty) help to maintain the strategic integrity of the system (i.e. a consensus about further development of the Euro-Atlantic system). The Alliance is a security structure with a wide network of formal and informal mechanisms for coordination and consultations.

\footnotetext{
${ }^{11}$ The North Atlantic Treaty, Washington D.C., 4 April 1949, http://www.nato.int/docu/basictxt/treaty. htm, 08102011

12 "NATO's Role in Building Cooperative Security in Europe and Beyond", Speech by NATO Secretary General Javier Solana at the Yomiuri Symposium on International Economy, Tokyo, Japan, October 15, 1997 , http://www.nato.int/cps/en/SID-E1446FA7-1505145B/natolive/opinions_25561.htm?selectedLocale=en, 08 102011
} 
In addition, NATO has various formats for practical cooperation in such fields as logistics, standardization, communications and information systems, civil emergency planning, scientific research, training and exercises, public diplomacy, meteorology, military oceanography and many other areas. ${ }^{13}$

The third ring. Article 5 establishes a mechanism of deterrence, which has been in effect since the inception of NATO and has prevented external military aggression during and after the Cold War. ${ }^{14}$

The Declaration on Alliance Security adopted in 2009 at the Strasbourg/ Kehl Summit states that "Deterrence, based on an appropriate mix of nuclear and conventional capabilities, remains a core element of our overall strategy." ${ }^{15}$ NATO gives considerable attention to various military and political initiatives, which aim at NATO's ability to defend its territory from external aggression.

NATO as a military organization ensures its efficiency by maintaining an integrated military structure, common defence planning mechanism, rapid response force, nuclear deterrence capability, integrated air defence system, common financing of various infrastructure projects, effective network of operational headquarters and other capabilities.

In the light of the changing international security environment, NATO is more and more focused on the ability to react and neutralize non-traditional security challenges: cyber attacks, terrorism, proliferation of WMD, etc. ${ }^{16}$

The fourth ring. A policy of dialogue and cooperation ${ }^{17}$ plays an important role in NATO strategy. It allows the Alliance to enhance the zone of "stability and security" beyond its territory, thus preventing the emergence of new security

\footnotetext{
${ }^{13}$ About NATO's role and institutions in these areas see: NATO Handbook, Brussels: NATO Public Diplomacy Division, 2006, p. 273-349.

14 9/11 terrorist attacks in the USA could be considered as the only exception, as the Article 5 of the North Atlantic Treaty was officially invoked for the first time in NATO's history. See: Buckley, E, „Invoking Article 5“, NATO Review, Summer 2006, http://www.nato.int/docu/review/2006/issue2/english/art2. html, 08102011.

${ }^{15}$ Declaration on Alliance Security, issued by the Heads of State and Government participating in the meeting of the North Atlantic Council, Strasbourg/Kehl, 4 April 2009, http://www.nato.int/cps/en/natolive/ news_52838.htm, 08102011.

${ }^{16}$ See, for example: Comprehensive Political Guidance, Endorsed by NATO Heads of State and Government on 29 November 2006, http://www.nato.int/cps/en/SID-94B7F554-9A0B094E/natolive/official_ texts_56425.htm, 08102011

${ }^{17}$ The process of dialogue and cooperation actually institutionalized NATO as a global political forum. It involves such cooperation programs as Mediterranean dialogue, NATO-Russia Council, Euro-Atlantic Partnership Council, Partnership for Peace, NATO-Ukraine Commission, NATO-Georgia Commission, Istanbul Cooperation Initiative. The ties with global partners - Australia, South Korea, Japan, New Zealand - were also amplified. Furthermore, in recent years the Alliance conducted intensive enlargement policy - in 2004 seven new countries, in 2009 - two (Albania and Croatia) became members of NATO.
} 
threats. ${ }^{18}$ Article 2 of the North Atlantic Treaty highlights that member states will "contribute toward the further development of peaceful and friendly international relations by strengthening their free institutions, by bringing about a better understanding of the principles upon which these institutions are founded, and by promoting conditions of stability and well-being." 19

Various partnership programs and forms of practical cooperation (common exercises and training, assistance in the field of defence sector reform, etc.) directly contribute to the stability projection beyond NATO. However, the Alliance has not developed close relations with such actors as China, India, Brazil and other rising powers, as well as various regional organizations (African Union, Collective Security Treaty Organization, etc.). In addition, NATO's cooperation with the EU and UN is often burdened by various political obstacles (as in, for example, the Cyprus conflict).

NATO's engagement in crisis management and stabilization activities is based on a postmodern concept of reacting to threats where they emerge. The essential idea of this concept is well reflected in the famous phrase by NATO's Secretary General L. Robertson: "if we don't go to Afghanistan, Afghanistan will come to us." ${ }^{20}$ Thus, the Alliance responds to various threats anywhere in the world, if it is needed for NATO's security interests.

Another important element of stability projection is the transformation of NATO's capabilities. In order to ensure the success of crisis management operations and effectively neutralize asymmetric threats beyond its territory ${ }^{21}$, NATO

\footnotetext{
${ }^{18}$ About the need for close cooperation with other actors in the international system see: „Global NATO?“, Speech by NATO Secretary General, Jaap de Hoop Scheffer at the Clingendael Institute, The Hague, Netherlands, 29 Oct. 2004, http://www.nato.int/cps/en/natolive/opinions_21123.htm, 08102011.

„Global NATO: Overdue or Overstretch?“", Speech by NATO Secretary General, Jaap de Hoop Scheffer, at the SDA Conference, Brussels, 06 Nov. 2006, http://www.nato.int/cps/en/natolive/opinions_22449.htm, 08 102011.

${ }^{19}$ The North Atlantic Treaty, Washington D.C., 4 April 1949, http://www.nato.int/docu/basictxt/treaty. htm, 08102011

${ }^{20}$ NATO, "Speech by NATO Secretary General at the National Defense University", Washington D.C., USA, 29 Jan. 2003, http://www.nato.int/docu/speech/2004/s040129a.htm, 08102011.

${ }^{21}$ Comprehensive Political Guidance endorsed in Riga summit (2006) state that NATO has to be able to conduct several different operations simultaneously outside NATO in unpredictable environment. Over the next 10 to 15 years NATO's forces are required, inter alia, to be able to (i) conduct and support multinational joint expeditionary operations far from home territory with little or no host nation support; (ii) deter, disrupt, defend and protect against terrorism and various asymmetric threats, including weapons of mass destruction; (iii) protect information systems of critical importance to the Alliance against cyber attacks; (iv) bring military support to stabilisation operations and reconstruction efforts across all phases of a crisis; (v) conduct operations in demanding geographical and climatic environments; (vi) conduct operations taking account of the threats posed by weapons of mass destruction and chemical, biological, radiological and nuclear hazards, etc. See: Comprehensive Political Guidance Endorsed by NATO Heads of State and Government", 29 November 2006, http://www.nato.int/docu/basictxt/b061129e.htm, 08102011.
} 
has not only created a multifunctional rapid response force, but also transformed its military structures, adapting them to its asymmetric security environment. ${ }^{22}$ The process of changing capabilities well illustrates NATO transformation from regional alliance based on territorial defence to globally connected crisis response mechanism.

In sum, our brief analysis based on the model of four concentric rings suggests that NATO can be considered an effective cooperative security system (see Figure 2).

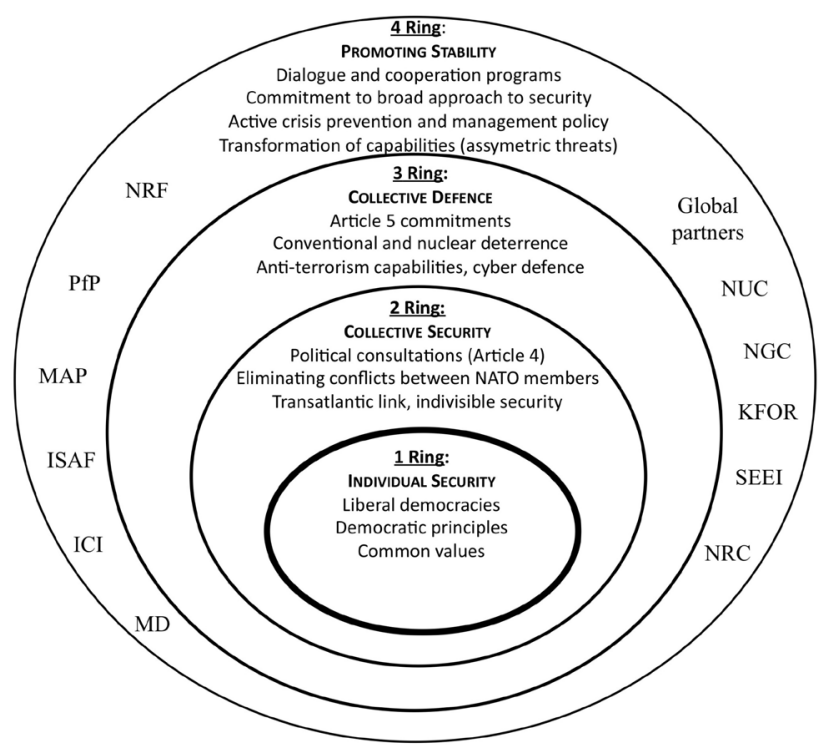

Figure 2. NATO as a cooperative security system: the main features ${ }^{23}$

\footnotetext{
${ }^{22}$ In Prague Summit, NATO decided to create the NATO Response Force which is mobile, interoperable, highly ready and technologically advanced multinational force made up of land, air, maritime and special forces components. It can be rapidly deployed to high intensity missions by the decision of the North Atlantic Council. See: Prague Summit Declaration issued by the Heads of State and Government participating in the meeting of the North Atlantic Council. 21 November 2002, http://www.nato.int/docu/pr/2002/p02127e. htm, 0810 2011; "NATO after the Prague Summit", Speech by NATO Secretary General Lord Robertson at the Konrad Adenauer Stiftung, Berlin, Germany, 12 Dec. 2002, http://www.nato.int/cps/en/natolive/opinions_19600.htm, 08102011

${ }^{23}$ Abbreviations: NRF - NATO Response Force; PfP - Partnership for Peace; MAP - Membership Action Plan; ISAF - International Security Assistance Force; ICI - Istanbul Cooperation Initiative; MD - Mediterranean Dialogue; NRC - NATO-Russia Council; KFOR - Kosovo Force; NGC - NATO-Georgia Commission; NUC NATO-Ukraine Commission.
} 


\section{Analysis of NATO Strategic Concepts}

\subsection{The 1999 Strategic Concept: Credible Collective Defence and Security of the Euro-Atlantic Region ${ }^{24}$}

\subsubsection{The First Ring: Individual Security}

The 1999 Strategic Concept states that the essential and enduring purpose of NATO is to safeguard the freedom of its members (i.e. states) by political and military means (\$6). Neither individual nor societal security is mentioned among the fundamental security tasks. ${ }^{25}$

Rather modest attention is also given to a normative (human rights) dimension, which is restricted to general remarks about NATO as an organization based on democratic values, human rights and the rule of law, seeking to establish peaceful order in Europe.

\subsubsection{The Second Ring: Collective Security}

The 1999 Strategic Concept includes some provisions which clearly reflect the principles of collective security. One of four "fundamental security tasks" identified in the document is to ensure stability and security in the Euro-Atlantic region, focusing on the promotion of democratic institutions, the peaceful resolution of disputes and the prevention of conflicts $(\$ 10)$. In other words, the Strategic Concept provides the basis for ensuring stability within the system.

Accordingly, consultation mechanisms between the countries play a substantial role in the document. On the basis of Article 4 of the North Atlantic Treaty, political consultations are considered a crucial measure in order to ensure the effectiveness of NATO as a transatlantic security forum and the successful coordination of activities between the member-states $(\$ 10)$. The Strategic Concept also highlights the importance of NATO as a fundamental practical and institutional expression of transatlantic link, which ensures the indivisibility of security between

\footnotetext{
${ }^{24}$ Analysis in this sections is made on the basis of 1999 NATO Strategic Concept. (The Alliance's Strategic Concept, approved by the Heads of State and Government participating in the meeting of the North Atlantic Council“, Washington D.C., 23-24 April 1999). Further references will be provided only in case of directly quoting the document.

${ }^{25}$ On the other hand, the preamble of the North Atlantic Treaty mentions the commitment to safeguard the freedom, common heritage and civilisation of their peoples, founded on the principles of democracy, individual liberty and the rule of law. See: the North Atlantic Treaty, Washington D.C., 4 April 1949, http:// www.nato.int/docu/basictxt/treaty.htm, 08102011.
} 
North America and Europe $(\$ 7,27)$. The document also places strong emphasis on Allied solidarity, strategic unity and coherence $(\$ 8,41)$.

\subsubsection{The Third Ring: Collective Defence}

Deterrence and defence against any form of aggression is considered as one of four fundamental security tasks in 1999 Strategic Concept (\$10).

The commitments of Article 5 are also clearly demonstrated in the document, focusing on various practical measures of collective defence and effective deterrence: military planning and exercises, interoperability of Allied forces, defence infrastructure in the member states, standardization of various military procedures, etc. $(\$ 28,29,41,42)$.

The 1999 Strategic Concept pays particular attention to capability development and provides a detailed description of military requirements for NATO forces (\$41-61). The main role of NATO’s military forces is "to protect peace and to guarantee the territorial integrity, political independence and security of member states. The Alliance's forces must therefore be able to deter and defend effectively, to maintain or restore the territorial integrity of Allied nations and - in case of conflict - to terminate war rapidly by making an aggressor reconsider his decision, cease his attack and withdraw." 26 The document also indicates various requirements with regard to size and geographical distribution of NATO forces, parameters of command structure (operational headquarters and integrated military structure), development of multinational capabilities, etc.

The concept also defines the main parameters for NATO nuclear strategy. It is stated that conventional forces of NATO are not sufficient to ensure credible deterrence, and a nuclear arsenal is therefore required. The main purpose of the nuclear forces "is political: to preserve peace and prevent coercion and any kind of war". ${ }^{27}$ Besides, the nuclear arsenal of NATO is considered a "supreme guarantee of security", which also plays the role of "essential political and military link" between Europe and North America. NATO commits to maintain its nuclear capability, which has to be flexible enough to ensure a robust deterrence posture (\$62-64).

However, the Strategic Concept also states that nuclear weapons could be used only in "extremely remote" circumstances and gives a lot of attention to NATO's active nuclear disarmament policy after the end of the Cold War

The document rather explicitly assesses the strategic security environment, highlighting its unpredictability. Conventional aggression against the Alliance is seen as "highly unlikely"; however, the "possibility of such a threat emerging over the longer term exists" ${ }^{28}$ Ethnic and religious rivalries, territorial disputes, human rights

\footnotetext{
${ }^{26}$ The Alliance's Strategic Concept, 1999, $\$ 47$.

27 The Alliance's Strategic Concept, 1999, \$ 62 .

${ }^{28}$ The Alliance‘s Strategic Concept, 1999, \$ 20.
} 
abuse and dissolution of states are mentioned among the main sources of regional instability, which can have direct security implications for the Alliance (\$20-24).

In addition, the Strategic Concept emphasizes the importance of powerful nuclear forces outside NATO $(\$ 21)$ and the proliferation of weapons of mass destruction and their means of delivery, including the increasing role of non-state actors.

\subsubsection{The Fourth Ring: Promoting Stability}

Crisis management policy plays a substantial role in the 1999 Strategic Concept, focusing on NATO's ability to prevent conflicts and conduct various crisis management operations. The concept of partnerships also is of key importance in the document. In order to ensure the stability and security of the Euro-Atlantic area, NATO has to develop various programs of partnerships, cooperation and dialogue. NATO commits not only to ensure effective defence of its member states, but also actively contribute to consolidation of regional security and stability (\$31-33).

NATO supports a broad concept of security, which embraces various political, economic, social factors. In accordance, the need for close coordination with other actors in the international system is highlighted.

According to the Strategic Concept, NATO seeks to strengthen stability and promote democratic processes in the Euro-Atlantic security system by (\$31-39):

- Continuing an open door policy (on the basis of Article 10 of the North Atlantic Treaty, i.e. leaving the door open for all European democracies, which seek membership and assume the responsibilities and obligations of membership);

- implementing an active partnerships policy. Special attention is given to Euro-Atlantic Partnership Council, Partnership for Peace, relations with Ukraine and Mediterranean Dialogue. The Strategic Concept contains a rather abstract definition of NATO-Russia relations, stating that Russia plays a unique role in the Euro-Atlantic security system and enduring partnership is important for regional stability and security;

- continuing an active policy in the field of disarmament, arms control and non-proliferation. CFE, START and Comprehensive Test Ban treaties are considered to play particularly significant role in this respect.

- continuing support of the development of the European Security and Defence Identity within the Alliance, allowing the EU to use NATO capabilities for Western European Union-led operations.

- conducting active crisis prevention and management policy, i.e. using various political and military measures to prevent conflicts and ensure their effective management; 
- ensuring close cooperation between civilian and military dimension, as various civilian capabilities become increasingly important for the implementation of military tasks in such areas as logistics, communications, medical support, etc.

\subsection{The 2010 Strategic Concept: Global Connections, Security "At Home", New Threats and Crisis Management.}

\subsubsection{The First Ring: Individual Security}

The 2010 Strategic Concept only briefly highlights that NATO countries create a values-based community committed to the principles of individual liberty, democracy, human rights and the rule of law $(\$ 2)$.

\subsubsection{The Second Ring: Collective Security}

As in 1999 document, the 2010 Strategic Concept highlights that the fundamental and enduring purpose of NATO is to ensure (by using political and military means) the freedom and security of NATO countries (\$1).

The document also emphasizes the importance of transatlantic link and indivisible security between Europe and North America. NATO is considered as the main forum for transatlantic security policy $(\$ 3,5)$.

\subsubsection{The Third Ring: Collective Defence}

Collective defence, on the basis of Article 5 of the North Atlantic Treaty, is considered as one of the three "core tasks" of NATO, identified in the new concept. In a new addition to the concept, more attention is given to new security challenges, such as cyber attacks, international terrorism, disruption of vital communication and energy transport routes $(\$ 7-15)$.

NATO commits to direct more attention to capabilities needed for the prevention of cyber attacks or neutralizing their impact (focus on cyber capabilities within NATO defence planning mechanism, better coordination of developing national capabilities and eventual response strategies, etc.) (\$19).

The Alliance also takes more responsibility in the field of energy security, including protection of critical infrastructure and transit areas and lines, consultations among Allies and contingency planning. 
The Strategic Concept emphasizes that the threat of a conventional attack against NATO territory is "low"; however, "the conventional threat cannot be ignored" 29 , especially because of proliferation of ballistic missiles as well as nuclear weapons and other weapons of mass destruction, and their means of delivery. Accordingly, emphasis is put on missile defence capability, aimed at defending NATO's territory from the ballistic missile attacks. Such defensive capability is seen as the "core element" of NATO's collective defence $(\$ 19)$.

As in the 1999 document, the 2010 Strategic Concept mentions the proliferation of weapons of mass destruction, instability and conflicts beyond NATO as important elements of NATO's security environment. Though NATO does not consider any country to be its adversary, "no one should doubt NATO's resolve if the security of any of its members were to be threatened." ${ }^{30}$ The document states that a nuclear weapon could be used only under "extremely remote" circumstances; however, NATO will remain a nuclear alliance "as long nuclear weapons exist". ${ }^{31}$ Further, NATO's activities in the field nuclear disarmament are related to reciprocal actions from Russia's side, focusing on enhanced transparency and relocation of European-based Russian nuclear weapons.

The 2010 Strategic Concept directs less attention to various practical means of collective defence (military planning, requirements for forces and capabilities, defence infrastructure, etc.). However, it clearly expresses NATO's political will to conduct a policy of visible assurance (exercises, training, contingency planning) $(\$ 19)$, which is aimed at reassuring member-states (especially, countries in Central and Eastern Europe) about NATO's readiness, credibility and commitment to ensure their security and response to full range of threats.

The document strongly highlights the importance of developing military capabilities for expeditionary operations $(\$ 19,25)$, as well as strengthening the ability to react to CBRN attacks.

\subsubsection{The Fourth Ring: Promoting Stability}

In comparison with the 1999 document, the 2010 Strategic Concept gives more attention to NATO's role in the field of crisis management. It is stated that various crises and conflicts beyond NATO can pose a direct threat to Alliance's territory and populations. NATO is therefore committed to engage to prevent and manage crises, conduct post-conflict stabilisation and support reconstruction. The Strategic Concept emphasizes that NATO has unique conflict management capacities $(\$ 23)$.

\footnotetext{
${ }^{29}$ Strategic Concept For the Defence and Security of The Members of the North Atlantic Treaty Organisation, 2010, $\$ 8$.

${ }^{30} \mathrm{Ibid}, \$ 16$.

${ }^{31}$ Ibid, $\$ 17$.
} 
One of the crucial innovations of the new Strategic Concept is that considerable attention is paid to the development of civilian capabilities. The document emphasizes that operations in Afghanistan and Western Balkans have showed the importance of the Comprehensive Approach, i.e. the integration of civilian and military instruments and close cooperation with other international actors, including various non-governmental organizations $(\$ 21)$.

In order to ensure the effectiveness of crisis management operations, NATO commits to: (i) strengthening the exchange of intelligence; (ii) strengthening the readiness to conduct expeditionary operations (doctrines and capabilities); (iii) developing appropriate but modest civilian crisis management capability and improve coordination with various civilian partners; (iv) ensuring an integrated civilian-military planning mechanism; (v) developing the capacity to train local forces in crisis zones (\$25).

The 2010 strategy basically reaffirms the provisions of the 1999 document with regard to NATO's role in arms control (including conventional arms control regime in Europe), and non-proliferation. The new concept also maintains the commitment to open door policy by emphasizing that NATO's door remain open for European democracies, "which share the values of our Alliance, which are willing and able to assume the responsibilities and obligations of membership, and whose inclusion can contribute to common security and stability." 32

The new Strategic Concept directs even more attention to partnerships. Close cooperation with partners in various fields (primarily - NATO-led missions) is seen as the key precondition for success. NATO is committed to strengthening partnership policy by: (i) developing practical cooperation with other international organizations; (ii) ensuring intensive security consultations with partners; (iii) giving operational partners a structural role in shaping strategy and decisions on NATO-led missions; (iv) deepening cooperation with the UN (more active political consultations, etc.); (v) ensuring productive strategic partnership between NATO and the EU (enhanced practical cooperation in such areas as international operations, capability development, etc.) (\$28-35). However, the new Strategic Concept does not even mention such international organizations as Organization for Security and Cooperation in Europe (OSCE) or African Union.

The 2010 strategy pays more attention to relations with Russia, emphasizing that NATO-Russia cooperation is strategically important, NATO does not pose a threat to Russia and expects positive reciprocal steps from Russian side. NATO is committed to strengthening political consultations and practical cooperation in such fields as missile defence, anti-terrorism, piracy, etc (\$34).

\footnotetext{
32 Ibid, $\$ 17$.
} 
Table 1. NATO as a cooperative security system: The main elements of the 1999 and 2010 Strategic Concepts

\begin{tabular}{|c|c|c|}
\hline & 1999 m. Strategic Concept & $2010 \mathrm{~m}$. Strategic Concept \\
\hline $\begin{array}{l}1 \text { ring: } \\
\text { individual } \\
\text { security }\end{array}$ & $\begin{array}{l}\text { - Main object of security - nations. } \\
\text { - Little attention to normative dimension } \\
\text { (human rights, democratic principles) }\end{array}$ & $\begin{array}{l}\text { - Main object of security - } \\
\text { nations and populations. } \\
\text { - Little attention to normative } \\
\text { dimension (human rights, } \\
\text { democratic principles) }\end{array}$ \\
\hline $\begin{array}{l}2 \text { ring: } \\
\text { collective } \\
\text { security }\end{array}$ & $\begin{array}{l}\text { - Main purpose of NATO - to safeguard } \\
\text { the freedom and security of NATO } \\
\text { members by military and political } \\
\text { measures. } \\
\text { - Emphasis on the importance of } \\
\text { security in the Euro-Atlantic region } \\
\text { (internal stability of the system), } \\
\text { transatlantic link (NATO as a political } \\
\text { and institutional link between Europe } \\
\text { and North America) and political } \\
\text { consultation (on the basis of Article } 4 \text { of } \\
\text { the North Atlantic Treaty) } \\
\text { - Considerable attention to NATO } \\
\text { solidarity, strategic unity and coherence. }\end{array}$ & $\begin{array}{l}\text { - Main purpose of NATO - to } \\
\text { safeguard the freedom and } \\
\text { security of NATO members by } \\
\text { military and political measures. } \\
\text { - Emphasis on transatlantic link } \\
\text { (NATO as a forum for security } \\
\text { policy), indivisible security } \\
\text { and political consultations } \\
\text { (coordination of actions and } \\
\text { strategic decisions). }\end{array}$ \\
\hline $\begin{array}{l}3 \text { ring: } \\
\text { collective } \\
\text { defence }\end{array}$ & $\begin{array}{l}\text { - Focus on deterrence and defence. } \\
\text { - Identification of practical measures } \\
\text { for effective collective defence, detailed } \\
\text { requirements for NATO forces. } \\
\text { - Nuclear arsenal has a political role - to } \\
\text { preserve peace and prevent coercion } \\
\text { and any kind of war. Nuclear capability is } \\
\text { considered as a supreme guarantee of } \\
\text { Allied security. } \\
\text { - Conventional aggression against } \\
\text { NATO is considered as highly unlikely, } \\
\text { however, the possibility of such a threat } \\
\text { over the longer term exists. } \\
\text { - Emphasis on unpredictability of } \\
\text { security environment and proliferation } \\
\text { of WMD. } \\
\text { - Instability in the neighbourhood } \\
\text { of NATO as an important source of } \\
\text { instability. }\end{array}$ & $\begin{array}{l}\text { - Deterrence, based on a mix } \\
\text { of nuclear and conventional } \\
\text { capabilities, remains the core } \\
\text { element of NATO's overall } \\
\text { strategy. } \\
\text { - Emphasis on new security } \\
\text { challenges (especially cyber } \\
\text { attacks) and capabilities needed } \\
\text { for their neutralization. } \\
\text { - The likelihood of conventional } \\
\text { attack is low, however, the risk } \\
\text { remains, especially in the light of } \\
\text { growing threat of ballistic missile } \\
\text { attack against NATO. } \\
\text { - Missile defence capability is } \\
\text { considered as a core element of } \\
\text { NATO's collective defence. } \\
\text { - Focus on visible assurance } \\
\text { policy (demonstration of NATO's } \\
\text { commitment and credibility). } \\
\text { - NATO will remain nuclear } \\
\text { alliance as long as there are } \\
\text { nuclear weapons in the world. }\end{array}$ \\
\hline
\end{tabular}




\begin{tabular}{|c|c|c|}
\hline $\begin{array}{l}4 \text { ring: } \\
\text { promoting } \\
\text { stability }\end{array}$ & $\begin{array}{l}\text { - Focus on crisis prevention and } \\
\text { management (especially within the Euro- } \\
\text { Atlantic region) policy. } \\
\text { - Commitment to broad approach to } \\
\text { security, including various political, } \\
\text { economic, social factors. } \\
\text { - UN is recognized as playing key role in } \\
\text { international arena. } \\
\text { - Commitment to continue open } \\
\text { door policy, further develop various } \\
\text { partnerships (EAPC, PfP, MD, relations } \\
\text { with Ukraine, etc.), support for European } \\
\text { security and defence identity within the } \\
\text { Alliance. } \\
\text { - NATO-Russia relations are defined } \\
\text { in a rather abstract way, stating that } \\
\text { Russia plays a unique role in Euro- } \\
\text { Atlantic security system; NATO-Russia } \\
\text { partnership is essential for international } \\
\text { stability. } \\
\text { - Commitment to open door policy, in } \\
\text { line with Article } 10 \text { of the North Atlantic } \\
\text { Treaty. } \\
\text { - Commitment to contribute to } \\
\text { international arms control, disarmament } \\
\text { and non-proliferation endeavours. }\end{array}$ & $\begin{array}{l}\text { - Focus on NATO's role in the } \\
\text { field of crisis management } \\
\text { (exchange of intelligence, } \\
\text { doctrines and capabilities, } \\
\text { training of local forces, lessons } \\
\text { learned in Afghanistan and } \\
\text { Western Balkans). } \\
\text { - Commitment to develop civilian } \\
\text { crisis management capabilities } \\
\text { and improve coordination with } \\
\text { various civilian actors. } \\
\text { - Key role for partnerships: active } \\
\text { security consultations, structural } \\
\text { role for operational partners } \\
\text { in shaping NATO decisions, } \\
\text { development of various } \\
\text { partnership programs. } \\
\text { - UN is recognized as playing } \\
\text { key role in international arena. } \\
\text { - NATO reaffirms its commitment } \\
\text { to contribute to international } \\
\text { arms control (including } \\
\text { conventional arms control } \\
\text { regime in Europe) and non- } \\
\text { proliferation. } \\
\text { - Maintained commitment to } \\
\text { open door policy. } \\
\text { - NATO does not pose any } \\
\text { threat to Russia and expects } \\
\text { reciprocal actions and enhanced } \\
\text { cooperation in such areas } \\
\text { as missile defence, counter- } \\
\text { terrorism, counter-narcotics, } \\
\text { counter-piracy, etc. }\end{array}$ \\
\hline
\end{tabular}

\subsection{Assessment:}

\section{What Is New in the New Strategic Concept?}

\subsubsection{No Fundamental Changes}

Despite substantial transformation of the international security system since 1999, the key provisions in both Strategic Concepts remain unchanged: collective defence, effective deterrence (including nuclear deterrence), transatlantic link, security consultations, partnerships, indivisible security between North America and Europe, open door policy and crisis management capacity remain crucial elements of the Alliance. 


\subsubsection{Collective Defence: Remaining Importance and Changes}

The 1999 document devotes a lot of attention (from political, as well as military perspectives) to NATO's ability to ensure effective collective defence in accordance with Article 5 of the North Atlantic Treaty. The 2010 Strategic Concept is less focused on various practical measures of collective defence; however, political commitment to ensure visible assurance and demonstrate NATO's credibility (exercises, training, contingency planning, etc.) is clearly expressed.

The 2010 Strategic Concept gets NATO "back to basics". After the 9/11 events NATO's reform basically was focused on the asymmetric threats, trying to transform the Alliance into a multifunctional crisis response mechanism. Such tendencies are well illustrated by the Comprehensive Political Guidance (adopted in 2006 Riga Summit), which clearly promotes expeditionary profile for the Alliance, focusing on international terrorism and other asymmetric challenges. The situation was changed by the resurgence of Russia (especially, 2008 war in Georgia), which pushed NATO back to the concept of universal security structure (security "at home" + effective crisis management "out the area"), thus reassuring sensitive countries in the Eastern and Central Europe and ensuring solidarity within the Alliance. Paradoxically, this "coming back" of NATO actually happened in the light of actively promoting a "reset" policy between US/NATO and Russia.

The 2010 Strategic Concept has two important innovations: (1) new threats (first and foremost, cyber attacks), though not directly, are put within the notion of collective defence, thus indirectly broadening the interpretation of "armed attack", which is used in the Article 5 of the North Atlantic Treaty; (2) NATO's collective defence is directly connected with the threat of ballistic missile defence. In fact, this connection can be regarded as a strategic move, which justifies and legitimizes NATO as a collective defence organization in the twenty-first century, as the most realistic security challenge for many NATO countries - Russia - is officially considered a key strategic partner. In other words, NATO could not allow itself to define its identity on the basis of confrontation with Russia, and therefore the ballistic missile threat was incorporated into the strategy as a new element legitimizing collective defence.

\subsubsection{Civilian Capabilities}

Development of NATO's independent civilian capabilities is a long-lasting and sensitive issue among the Allies. Some countries consider NATO primarily as a military alliance, which should leave civilian tasks to the European Union and other international organizations. In this light, the new commitment to develop 
"civilian crisis management capability" in the 2010 Strategic Concept can be considered an important turning-point in the evolution of NATO as a military organization. However, the new strategy also emphasizes that NATO's ambitions in this field remain modest; the Alliance is not going to take a lead role.

\subsubsection{A Different Spectrum of Activities}

The driving force of the 1999 Strategic Concept was NATO's operation in Kosovo. In accordance, the document is based on a regional approach, focusing on responsibility for the security of the Euro-Atlantic region and potential sources of instability its neighbourhood. In other words, NATO's "out of area" activities in essence were restricted to the Euro-Atlantic region.

Evidently, the 2010 document is highly influenced by the lessons learned from NATO's operation in Afghanistan: the Alliance is committed to strengthen various aspects of crisis management (including stabilization and reconstruction tasks), ensure broader involvement of partners into the operational decision making process, etc. The global spectrum of NATO's activities is also reflected in the assessment of strategic environment, which includes various ecological, climate change, resource factors, etc. In addition, the new Strategic Concept apparently is aimed at strengthening NATO as a global political forum. Yet, some of the programs remain rather inefficient (e.g. Istanbul Cooperation Initiative) or struggling due to political obstacles (e.g. NATO-Ukraine commission).

\subsubsection{Differences of the Threat Assessment}

Both Strategic Concepts highlight the importance of certain security challenges (proliferation of the WMD, instability in the neighbourhood, etc.). Yet, the 2010 strategy gives considerably more attention to new/unconventional threats (cyber attacks, terrorism, disruption of energy supplies, etc.), which (although mentioned) play a minimal role in the 1999 Strategic Concept.

\subsubsection{Relations with Russia: the Political Contribution to a "Reset" Policy}

The renewal of relations with Russia was one of the key priorities of the current US administration and NATO's Secretary General. Accordingly, in 
comparison with 1999 document (rather brief definition of NATO-Russia relations), the 2010 Strategic Concept devotes much more attention to various fields of eventual practical cooperation (missile defence, as well as counter-terrorism, counter-narcotics, counter-piracy, etc.).

However, basic disagreements between NATO countries regarding policy vis-ą-vis Russia have not disappeared. Therefore, the actual implementation of the Strategic Concept will face many political difficulties. One of the crucial indicators to assess actual progress of NATO-Russia relations will be the cooperation in the field of missile defence, which has not achieved any considerable progress yet.

\subsubsection{The Puzzle of Nuclear Policy}

The new Strategic Concept well illustrates the fact that NATO is not firmly determined about the future of its nuclear policy. On the one hand, NATO is committed to the goal of creating the conditions for a world without nuclear weapons, thus supporting B. Obama's nuclear agenda outlined in his Prague speech in 2009. On the other hand, the new Strategic Concept reaffirms that strategic nuclear forces remain the "the supreme guarantee of the security of the Allies"33, while "deterrence, based on a mix of conventional and nuclear capabilities, remains a core element of our overall strategy". ${ }^{34}$ Notably, the provisions regarding nuclear policy are much more abstract compared to the 1999 document, as some key questions are left unanswered as a subject for further deliberations among nations.

The fundamental dilemma concerns the future of US sub-strategic nuclear weapons located in Europe. The US nuclear presence is an important practical expression of the US commitment to European security, supporting the principle of indivisible security, allowing the maintenance of strategic balance with Russia, contributing to deterrence and ensuring nuclear burden-sharing among the Allies (common planning, consultation, exercises, etc.).

However, maintaining sub-strategic nuclear weapons (and various supporting capabilities) is a considerable financial burden; moreover, their military value is questionable. Besides, some NATO countries (such as Germany) are politically committed to remove US weapons from their soil. The new Strategic Concept relates further reductions from NATO's side with reciprocal actions from Russia, which, supposedly, has a considerably bigger amount of sub-strategic nuclear

\footnotetext{
${ }^{33}$ Ibid, $\$ 18$.

${ }^{34}$ Ibid, §17.
} 
weapons in Europe ${ }^{35}$ Any negotiations with Russia about enhanced transparency and further reductions might become an important test for NATO's internal solidarity.

\subsubsection{European Union: Loud Commitments, Lack of Substance}

Despite emphasis on the need to strengthen the strategic partnership with the EU in various fields, practical cooperation remains constrained due to unsolved political issues (first and foremost, disagreements between Turkey, Greece and Cyprus). Despite considerable progress of the European security and defence policy during the last decade, crucial political matters were not resolved, including the question of establishing independent EU operational planning structures.

\subsubsection{Unanswered Questions}

Despite the long process (a year and a half) of developing the new Strategic Concept, the document does not provide answers to some fundamental questions regarding (1) NATO's functional and geographical (enlargement) limits; (2) NATO's priority operation in Afghanistan (exception or a rule, which will be followed in the future?); (3) NATO's role in terms of response to various security challenges generated by demographic problems, climate change, humanitarian crises, etc.; (4) the substantial financial and military gap between US and Europe; (5) the disproportionate operational burden-sharing; (6) the rigid decision making mechanism (all NATO's decisions will continue to be taken by consensus), etc. From this point of view one can claim that the new Strategic Concept did not meet the high expectations set by various analysts and politicians.

In addition, the new Strategic Concept could be criticized for several "artificial" commitments. Such ambitious goals as "creating the conditions for a world without nuclear weapons" (\$26) or "strengthen the conventional arms control regime in Europe" (\$26) are not very consistent with actual abilities of the Alliance.

\footnotetext{
${ }^{35}$ Knops, Raimond, "US non-strategic nuclear weapons in Europe: a fundamental NATO debate", Report of NATO Parliamentary Assembly, 2010, http://www.nato-pa.int/default.asp?SHORTCUT=2083, 08102011.
} 


\section{Conclusions}

The 2010 NATO Strategic Concept can hardly be considered a new strategic vision. The document is more "evolutionary" than "revolutionary"; instead of suggesting something fundamentally new, it is focused on generalizing the developments of NATO transformation, as well as changes in the strategic security environment during the last decade.

However, the new strategy clearly demonstrated the relevancy and importance of NATO in the twenty-first century. It reflects a modernized NATO, which can hardly be labelled a "relic of the Cold War". The process of preparing the new Strategic Concept actually was no less important than the actual document, as it provided the opportunity to "synchronize clocks" among the Allies, renew the commitment to each others security and demonstrate solidarity about the main tasks of NATO. The productive and successful NATO Summit in Lisbon was not shadowed by various disagreements, which had otherwise accompanied several previous NATO Summits.

The new Strategic Concept is a unique document because of its ability to ensure a proper balance between hardly compatible notions: (1) the model of regional organization vs. global spectrum of activities and partnerships; (2) commitment to open door policy vs. de facto "frozen" enlargement process; (3) considerable attention to security "at home" and reassurance policy vs. commitment to substantially improve relations with Russia; (4) the vision of nuclear-free world vs. maintaining NATO's nuclear deterrence policy.

In the light of cooperative security theory, NATO chose the model of a multifunctional security structure, which allows the combination of collective security (the second ring) and collective defence (the third ring) dimensions on the one hand with the active policy of promoting stability, operations and partnerships (the fourth ring) on the other. With regard to the individual security dimension (the first ring), NATO's role remains modest: common values, human rights and economic welfare are important elements of NATO's political rhetoric; however, their role remains rather limited in practical initiatives.

In summary: the compromised language in the new Strategic Concept only covered various problems (defence budget cuts, increasing gap between Europe and US, different security interests of various nations, etc.), which will restrain the effectiveness of the new strategy. The real implementation of an ambitious agenda in such fields as improving relations with Russia, the breakthrough of cooperation with the EU, development of civilian capabilities or creation of missile defence system will depend on the ability to address deeply rooted internal problems, which will require a favourable international environment, considerable resources and strong political will by the Allies.

January 2012 